Deidre Donnelly*

\title{
Globalised Girlhood: the teaching of femininity in Cosmopolitan and True Love
}

\begin{abstract}
A comparison of two South African women's magazines, Cosmopolitan and True Love, via both textual and reader analysis, examines their reception by teenage girls ${ }^{1}$. Do women's magazines serve as cultural developmental markers and informal educational devices in the passage from girlhood to adulthood? The study adopts a poststructuralist view on the gendered self as socially constructed within discourse. Women's magazines give 'femininity' a material form and are discursive sites-ofstruggle. Critical discourse analysis is applied to the text analysis, while the concept of 'interpretive repertoires' is applied to the focus group analysis.
\end{abstract}

Key words: Discourse analysis, femininity, gender, identity, interpretive repertoires, women's magazines

* Deirdre Donnelly is chief copy editor of O, The Oprah Magazine. Mailing address: deidre@assocmags.co.za

\footnotetext{
${ }^{1}$ At the time of this study (2000), no successful gender-specific teenage titles existed. Blush, which had been successful among white teenage girls during the 1980s, had closed, and StudentLife was aimed at late teens/early twenties. The situation has since changed.
} 


\section{INTRODUCTION}

\section{Media, discourse and identity}

The relationship between consumption and identity is informed by an awareness that commercial culture is 'an everyday spectacle which is available for symbolic interpretation and aesthetic investment' (Murray, 1998:iii), while identity is understood as 'an active set of performances which show to others, and to the person himself, the kind of person he desires to be taken to be' (Bocock, 1993:94). The media consumption practices of South African girls are of concern here, specifically the effects of global cultural influences on local identities. The primary focus is on media reception and the way in which teenage girls actively make sense of everyday media messages. This focus is based on the assumption that 'methods of making sense are the key to any kind of explanation of the self, as people's sense of themselves is in fact a conglomerate of these methods, produced through talk and theorizing'(Potter \& Wetherall, 1987:102).

Identities are social and cultural and are constituted within the 'network of meaning structures', or discourses, that circulate in all forms of social interaction and cultural production at any historical moment (Coullie, 1991:9). Discourses offer subject positions and 'help constitute us as social subjects' (Storey, 1999:79). Identity is constructed from the interaction of various discourses; always in the process of becoming, 'a moving towards rather than an arrival' (Barker, 1999:3). Identities are incomplete discursive constructions, which are 'as much about the future as the past' (Storey, 1999:3).

Through discourses 'we are offered subject positions which convey notions of what it is to be a man or a woman and which constitute our masculinity and femininity' (Pease, 2000:35). Discourses, found in the institutions responsible for the socialisation of the child, function by the authority of what is 'natural' (Weedon, 1987:98). It is when discourses have become naturalised that their ideological underpinnings are most powerful. The popularity of the magazine form requires that they be denaturalised and studied as 'cultural tools' (Laden, 2001:187). In terms of identity formation, I explore the possibility of self-transformation and selfimprovement which women's magazines, specifically, suggest. This concern stems from the recognition that "whether or not people have "real" access to the options [magazines] evoke, or whether they are able to afford them... their cultural force lies in their organizational or motivational/aspirational cogency' (Laden, 2000:11).

Women's magazines are highly contradictory and ambivalent forms. Their juxtaposition of feminist discourses with more traditional discourses of femininity is a source of constant tension. Since such magazines have long been representative of women's mass culture, 'the extreme contradictions between the positive and negative elements of the magazine's message provoke extreme reactions in women' (Wolf, 1990:70).

\section{Magazines in South Africa}

Women, students and people under 35 read magazines more than any other group (Claasen, 1998:139). The largest percentage of readers is between 16 and 24 (AMPS 2000). This group, constituting 34 percent of total magazine readership, prefer magazines over newspapers. Although the two publications under study are not 
directly targeted at teenage readers, they were the most familiar to black and white teenage girls during the study period (2000-2001), in the absence of any teenage specific titles ${ }^{2}$. Cosmopolitan, launched in South Africa in 1984, is part of the global brand that has come to typify the new generation of 'liberated' young women's magazines that emerged alongside second-wave feminism (Macdonald, 1995:87). True Love is one of the biggest-selling English-language women's glossies in the country. It was the first to appeal specifically to black women. True Love was relaunched in 1995 to attract a younger readership. The magazine has since dramatically increased its sales and readership ${ }^{3}$.

\section{THEORETICAL BACKGROUND}

Research into the women's magazine genre initially took the form of ideological and text-based analyses but, more recently, has become more reader-centric in its attempts to establish the role that these texts play in the construction of gender identities.

\section{The 'turn to the audience' in cultural and media studies}

Reception analysis is the result of a turn towards a more social-cultural approach to the study of media audiences, which departs from structural audience measurement techniques and the behaviourist media effects tradition (McQuail, 1994:47). The central tenet of reception analysis is that audiences are active in constructing meaning. There is thus potential for 'differential decoding' of messages according to the interpreter's social position, knowledge and experience. However, interpreters belong to 'interpretive communities', sharing similar experiences and discursive frameworks with others. Everyday life has become a major focus in contemporary cultural and feminist theory, owing to the awareness that cultural consumption occurs in the midst of daily routines (Bausinger, 1984:349).

When testing whether audience interpretations corresponded to their sociocultural background, David Morley (in Storey 1999:79) found this was only sometimes the case; many other instances suggested that decodings are not determined by socio-cultural position alone. Morley was constrained by Hall's three hypothetical reading positions, since they were not nuanced enough to account for interpretive contradictions (Moores, 1997:229). Morley instead proposed a genrebased model, which incorporated the different competencies of diverse audiences. It is not necessarily a viewer's social position alone that determines interpretation. Interpretation results more from the different discourses available to the viewer. Since class to a large extent determines a person's access to different discourse types, social position still plays a part in audience interpretation of media messages (Storey, 1999:80).

The term 'cultural capital' describes 'the unequal distribution of cultural practices, values and competencies characteristic of capitalist societies' (O'Sullivan et al., 1994:73). Pierre Bourdieu (1984) extends a class analysis to analysis of cultural consumption, arguing that just as some social groups have more economic capital and therefore greater material power, so do those groups have greater cultural power and correspondingly greater symbolic power (O’Sullivan et al., 1994). For Bourdieu, capital is not only economic but also includes symbolic capital, such as prestige,

\footnotetext{
2 This was confirmed during focus group studies.

${ }^{3}$ From October 1999 to October 2000, True Love saw a 22 percent increase in sales and a 39 percent increase in readership.
} 
status and authority, and cultural capital, which refers to culturally valued taste and consumption patterns (Laden, 2000).

\section{Gender, the media and the feminised body}

Gender is socially constructed; an unstable site-of-struggle, subject to continuous negotiation (Van Zoonen, 1994:33). The central concern behind gender-related media research lies in the assumption that media serve an important 'social learning function', as socialising agents. The inconclusive results of media effects research are attributed to the fact that socialisation is a long-term process, not necessarily confined to childhood, and because media interacts with other agents (McQuail, 1994:360). The media influence children's expectations and aspirations, as well as shape social behaviour, through presenting children with pictures of life and adulthood prior to actual experience. Early feminist studies examined media's role in the perpetuation of gender stereotypes through the depiction of women in a limited range of genderspecific roles. Advertising, specifically, came under investigation, owing to its constant preoccupation with gender, which it uses for its signifying power (Van Zoonen, 1994:67). Current gender-related media studies, however, focus on audiences and the contexts of reception, taking care not to universalise by considering variables other than gender.

Historically, women have been associated with specific kinds of media outputs deemed 'feminine', and therefore accorded lesser cultural value. However, the popularity of these forms, with their (overwhelmingly) female audience, suggests that certain 'needs' are being met. Most feminist research on gender and genre has focussed on soap opera, romance novels and women's magazines. Content is saturated with representations of 'femininity' and 'masculinity', which is why reception is a key site in which the construction of gender identity is assumed to take place (Van Zoonen, 1994). Such discourses 'work on the basis of consent by offering "obvious" or "natural" ways of being and forms of pleasure which go with them' (Weedon, 1987:100).

The process of feminisation is 'never-ending'. Media offer women 'fantasy modes' to 'try out different subjectivities' without the risks involved in real life (Van Zoonen, 1994:124). Women's magazines are crucially involved in shaping the characteristics of femininity, described as 'a state, a condition, a craft, and an art form which comprise a set of practices and beliefs' (Ferguson, 1983:1). Marjorie Ferguson's thesis draws an analogy between Durkheim's concept of a religious cult and the relationship between women's magazines and their readers. In this view, women's magazines create a 'cult of femininity' through the process of socialisation, by teaching 'young initiates' the rituals involved in becoming feminine. 'Femininity' has to be taught and constantly improved upon; it involves 'continuing education' and is a 'lifelong commitment' (Ferguson, 1983:8). The women's magazine thus serves as a vehicle for the ritualistic expression of a common identity based on gender.

Women's magazines make the connection between femininity and the consumption of specific products. Advertising combines with the other elements of the genre to provide 'a very potent formula indeed for steering female attitudes, behaviour and buying along a particular path of femininity, and a particular female worldview of the desirable, the possible, the purchasable' (Ferguson, 1983:2). Since ideas about 'masculinity' and 'femininity' are tied not just to sex difference but also to sexuality, 'there is a close relationship between the gendered codes of dress and ideas about sexuality’ (Entwistle, 2000:142). This conflation of sex, gender, 
appearance and sexuality is naturalised, and encourages the adoption of gender prescriptions. Indeed, 'the woman who does not conform to the concept of femininity devalues herself sexually and hence socially, since sexual values are an integral feature of society' (de Beauvoir, 1949 [1972]:692 in Thesander, 1997:174).

The body constitutes the 'environment of the self' and is thus inseparable from the self (Entwistle, 2000). The presentation of the self is linked to identity, and the fashion and advertising industries further ensure that self-identity is defined in terms of one's physical appearance (Negrin, 2000:84). The body has always been central to feminine identity and, when women decorate and adorn the body, they are participating in 'a system of meaning-creation' - the same system employed in advertising and media forms (MacDonald, 1995:192). Women's magazines are particularly involved in 'inviting' women to enter into this system of meaningcreation. Critics are divided into those who view the relationship between women and appearance rituals in negative terms, as a form of oppression, and those who view such rituals in a more celebratory light.

Although a 'celebratory, academic postmodernism' might find it "unfashionable - and highly "totalizing" - to talk about the grip of culture on the body' (Bordo, 1996:44), the reality is that 'sovereignty over the body is easier to assert rhetorically than to establish in practice' (MacDonald, 1995:193). To understand the relationship between patriarchy and the female body, it is useful to turn to Michel Foucault's (1982) notion of power, which rejects traditional understandings that rely on dichotomies, such as the categories of 'oppressed' and 'oppressor', because they fail to explain how 'power is manifested and constituted subjectively' (Pease, 2000:32). Wherever there is power, there is resistance, and the play of power is conducted through discourse. This understanding of the way in which discourses are internalised has been used to explain the way in which subordinated groups may in fact contribute to the perpetuation of their subordination, by internalising the discourse which is used to justify their subordination. Susan Bordo (1996:46) provides the example of how women may contribute to the perpetuation of female subordination by taking pleasure in, and perhaps feeling empowered by, the sexualisation of the female form. However, this is not to say that women have power 'in the production and reproduction of sexist culture' (Bordo, 1996:46) ${ }^{4}$.

The 'contradictory impulses to pamper and indulge oneself, and yet submit to regimes that at times emulate torture, find an echo in Foucault's theory of the body as a central location in the contest for power' (MacDonald, 1996:201). Foucault's later work on the 'ethics of the self' gives an account of a more active subject who works consciously towards self-improvement (Foucault, 1985 \& 1988) - an account which echoes the current self-help trend reflected in women's magazines.

\section{Women's magazines: historical background}

Women's periodicals are popular cultural forms where meanings about femininity, specifically, are contested and made. They are culturally significant because they '[work] at the intersection of these different economies - of money, public discourse and individual desire’ (Beetham, 1996:2).

The inclusion of fashion engravings in early magazines linked the female form with the pleasure of looking, which became 'endemic in the culture and central to the

\footnotetext{
${ }^{4}$ The concept of 'internalisation' has been criticised for offering a form of victim-blame in its suggestion that the 'oppressed' collude with their 'oppressors' in the perpetuation of their oppression (Pease, 2000: 34).
} 
tradition of the women's magazine' (Beetham, 1996:148). However, simultaneously, the female was depicted as imperfect and 'inevitably sick' (Beetham, 1996:41). This paradox defined femininity as 'at once artful as natural, self-made as given, desired object and desiring self' (Beetham, 1996:79). Product advertisements promised to heal this rift between the ideal and imperfect body and, in this way, 'femininity both defined and was defined by its likeness to the commodities with which it became associated' (Beetham, 1996:148).

\section{Sources of oppression and liberation: the ambivalence of women's magazines}

Angela McRobbie's (1981) analysis of the teen magazine Jackie is the most frequently cited example of early research which dismissed women's magazines as 'superficial-cum-repressive forms' (Murray, 1998:93). Women's magazines are exposed as playing on (and encouraging) deep-seated anxieties related to physical appearance by constructing women's bodies as 'problem-sites' in need of constant improvement (Beetham, 1996:41; Ferguson, 1983:59; Murray, 1998:98). The most notable response to McRobbie came from Elizabeth Frazer (1996:136), who suggested that teenage girls were, in fact, self-reflexive readers - not 'in the grip of' ideology, as suggested by McRobbie. Women are capable of being active, selfreflexive and 'resisting readers' (Beetham, 1996:11; Frazer, 1996:135; Hermes, 1995:145).

However, women's magazines are also praised for popularising feminist ideologies by providing a 'mix of feminism and femininity' (Friedan, 1991:66, cited in Craik, 1994:54). The alternating discourses of feminism and femininity within women's magazines suggest that the concepts of womanhood and femininity are fluid and subject to negotiation. The reading experience is correspondingly ambivalent and embodies 'repeated negotiations between "closure” and "open-endedness”' (Murray, 1994:66). Readers experience and exhibit contradictory feelings and views on magazines, which are often a source of tension (Hermes, 1995: 106; Murray, 1998:95) ${ }^{5}$. Women's magazines incite excitement and disappointment, pleasure and anxiety.

\section{The characteristics of the magazine commodity}

Magazines are 'meta-commodities' - commodities in themselves and also sites used for the dissemination of other commodities (Beetham, 1996:2; Laden, 1997:123). The 'move from reading to shopping became increasingly central to the genre' because the magazine positioned its readers as consumers and 'gave entry into a world of commodities' (Beetham, 1996:8).

Women's magazines are aspirational devices that present the reader with utopian lifestyle images, which offer an opportunity to fantasise about an 'ideal self'. In this way, magazines provide readers with 'moments of empowerment' by encouraging fantasies that may, in fact, strengthen particular identities (Hermes, 1995:51). It is both the 'taken-for-granted' and 'aspirational' qualities of women's magazines which point to their cultural significance.

\footnotetext{
${ }^{5}$ Wolf (1990: 62) recalls a woman who bought magazines as 'a form of self-abuse' because they gave her 'a weird mixture of anticipation and dread, a sort of stirred-up euphoria'. Similarly, Murray (1998: 95) reads women's magazines with 'varieties of irritation and enjoyment'.
} 


\section{Studies of South African magazines}

Research conducted into South African magazines has been done by Sonja Laden (1997; 1998; 2000) and Sally-Ann Murray (1994; 1998). Laden's examination of seven titles ${ }^{6}$ targeted at black readers argues for a 'cultural economy' approach (which draws on Bourdieu's understanding of symbolic capital as a particular embodiment of economic capital) over a more macrosocial political economy approach to the study of South African socio-cultural history. This approach allows Laden to 'give voice to "unofficial” versions of South Africa's modern-day sociocultural history' (2000:5). Laden identifies two primary dispositions that are more overtly present in magazines aimed at blacks readers, than those aimed at whites. The magazines are more evidently didactic and aspirational, and thus seem to serve as informal educational devices and modelling-apparatuses. Consumer magazines therefore suggest new lifestyles and 'ways of being' during times of socio-cultural change.

\section{Women's magazines, sexuality and teenage readers}

Women's magazines are informal educational devices, which have 'displaced a tradition of direct instruction by mothers and older women’ (Beetham, 1996:66). They provide popular education by 'reproducing skills and knowledges across generations and different cultural groups' (Craik, 1994:55). Teenage girls are likely to read the 'adult' titles, specifically those that are 'hip' in terms of aesthetics and tone, as a way of 'looking ahead' to an ideal, older self. A similar belief existed during the nineteenth century, when 'the transgressive daughter', who, it was anticipated, would be reading the magazine, came to stand for the entire readership. Even then, there was widespread anxiety over girls' access to knowledge of a sexual nature, so such content was deliberately excluded from women's publications, and readers were addressed as if young and inexperienced.

In girls' magazines, sexuality has replaced romance as the focus (McRobbie, 1996:192). During the 1990s, academics, journalists and members of parliament all debated the possibly detrimental effects of such sexual content on the socialisation of British girls (Gough-Yates, 2000:233). The Periodicals (Protection of Children) Bill required that publishers of young women's magazines display an age-suitability warning. The Bill was opposed, despite initially receiving widespread parliamentary support. It was argued that such a Bill would be impossible to monitor, and the proposed age ratings would result in a greater off-limits appeal to younger girls (Gough-Yates, 2000:232-233).

Mary-Jane Kehily (1999) explored the ways in which magazines aimed at the British adolescent female market serve as cultural resources for teaching and learning about issues of sexuality. Female respondents were found to be critical readers who perceived magazines as cultural markers in an 'externally constructed developmental process demarcated by age and gender' (1999:85). Magazines were seen to play a role in the process of moving from girlhood through adolescence and into womanhood. The study revealed that young people frequently referred to popular cultural forms as frameworks to discuss issues of sexuality.

\footnotetext{
${ }^{6}$ Drum, Bona, True Love, Pace, Thandi, Tribute and Ebony South Africa.
} 
With regards to sexual learning, Kehily found that magazines were more likely to be used as a resource for sexual learning by girls than boys ${ }^{7}$. This kind of sexual learning was strongly mediated by friendship groups. Girls reacted to sexual content with a group sensibility, collectively deciding which subjects were acceptable and which were 'over the top'. In general, girls were discerning and self-regulating readers who did not favour overly sexual magazine content. However, the girls did recognise that magazines can and do serve as useful information sources. Kehily (1999:33) concludes that friendship groups, and the collective magazine reading which they partake in, serve as key sites for the production of school-based femininities and sex-gender identities.

\section{Postmodernity, consumption and identity}

Sites of consumer culture, in the form of malls, serve as places of leisure for adolescent and teenage girls, and expressions of consumer culture, in the form of appearance styles and fashion, have long been 'arenas for female cultural production and knowledge' (Lewis, 1987:78). Knowledge about style and fashion trends is a form of private communication (much like sports talk is for men). Style imitation and fashion sense becomes an expression of 'textual competency' within their specific 'consumption community' (Lewis, 1987).

For aspirant youths, the media provide insight into the world of adulthood towards which they are moving. Concern stems from the belief that children and adolescents are perhaps less able to 'deconstruct' media messages than adults, and might be unconsciously influenced during the process of identity development. Since adolescence is a crucial moment in a person's psychosexual development, concerns about the effect of media images and cultural body ideals on the development of a healthy self-concept in girls are indeed warranted. The extreme objectification of the female body in the mass media 'prepares adolescent girls for internalizing the object of gaze', and the effect is that 'appearance is far more important than it should be to girls’ (Polce-Lynch, 1998:19).

\section{METHODOLOGY}

Critical discourse analysis (CDA) was used for analysis of the magazines, together with the concept of 'interpretive repertoires' put forward by discourse analysts from within the field of social psychology. The analysis of the linkages between discourse, ideology and power is made possible through the use of Norman Fairclough's (1992) three-part analytical framework. It is useful to identify how the study of intertextuality, genre and discourse types fits into the CDA three-part model. Intertextual analysis serves as a bridge between step one, description/text analysis, and step two, interpretation/processing analysis. Genre, similarly, 'cuts across the distinction between "description" and "interpretation"' (Fairclough, 1992:126). The analysis of 'discourse types', however, cuts across all three: textual analysis, analysis of discourse practice and socio-cultural analysis.

A 'qualitative' form of content analysis (of themes etc.) was the starting point for the comparative case study. The key to qualitative analysis of content is to be

\footnotetext{
${ }^{7}$ Kehily questioned boys about consumer titles, and did not consider the possibility that other material, such as pornography, might serve as resources for learning about sexuality and, if so, what the implications of such divergent sexual learning sources might be.
} 
aware of generic codes and conventions, since these 'indicate at a higher level what is going on in the text' (McQuail, 1994:276). Fifteen thematic categories were used to compare Cosmopolitan to True Love (and to compare Cosmopolitan with its television brand extension, The Cosmo Show). The choice of categories is not a wholly neutral process and I acknowledge that my choices were largely subjective especially when considering the nature of the magazine genre, where there is much overlap of categories and themes (Ferguson, 1983:29). The categories are: Love Relationships; Self-Help; Health; Celebrities; Sex; Social Issues; Real Life; Beauty; Self-Knowledge; Esoterica; Workplace; Relationship (other than romantic); Competitions; Fashion and Travel.

Focus group research aimed at establishing whether South African girls identify with the subject positions offered by women's magazines and whether or not they feel a sense of belonging to an 'imagined community' (or 'consumption community') of readers. My adoption of an interpretative framework is indicative of the larger 'turn to more “qualitative” research' within cultural studies (McQuail, 1994:47). Aspects of the methodology are associated with contemporary feminist media studies - self-reflexivity; the use of multiple methods, including the case study; and the interdisciplinary crossing of academic boundaries (Neuman, 1997:83).

Focus groups provided the main source of qualitative data. Non-probability convenience and snowball sampling was used to identify participants. Students within my department were approached, as were schools recommended by other researchers; and I placed a notice calling for True Love readers on university notice boards. My sample was, admittedly, not fully representative of South African youth, since consumer magazines are a relatively elite popular form, assumed to be read by urban and higher income groups displaying a high level of (media) literacy.

Five focus groups were conducted. Each consisted of between four and eight participants. They were generally urban, highly literate and belonged to the higher income bracket. Seven of the participants were 16 years old, followed by six 17 year olds. Most were white (18 in all, making up two thirds of the sample), followed by eight blacks, one Indian participant and one of mixed race.

The sessions lasted an hour and twenty minutes. Participants leafed through Cosmopolitan and True Love magazines, and one pre-recorded episode of The Cosmo Show was shown, to stimulate discussion. The groups were semi-structured and began with general questions on media consumption, followed by questions on television and magazines, and then the specific questions related to Cosmopolitan, True Love and The Cosmo Show. A question asked of each participant was to list both a positive and a negative feature of women's magazines. This question allowed each person to state her primary position on the topic of women's magazines and usually elicited the longest responses.

To organise her interview analysis, Joke Hermes (1995) focused on the 'repertoires' employed by her respondents when constructing different subjectivities for themselves during discussions about their magazine reading. 'Interpretive repertoires' describe recurrently used systems of terms for characterising and evaluating actions, events and other phenomenon (Potter \& Wetherall, 1987:149). These systems are often used with stylistic and grammatical coherence and are organised around one or more central metaphors. Interpretive repertoires are general resources for discourse construction and action available in a society at any given time (Wood \& Kroger, 2000:198). Within everyday reasoning, people normally draw on available repertoires (Hermes, 1995:204). 
My own use of repertoire analysis proceeds from Hermes' suggestion that checking whether the repertoires identified by herself could be transferred or generalised across different cases or settings would test their validity. The transcripts from my own focus groups were compared with the repertoires identified by Hermes, and I considered whether South African youth draw on different discursive resources for use in their self-constructions.

\section{CONTENT ANALYSIS}

\section{Cosmopolitan}

Cosmopolitan South Africa forms part of the global Cosmopolitan brand synonymous with fashion, sex and feminine street savvy. The typical reader is described as 'a woman in her freedom years, and in a phase in her life when time and money are her own' (www.naspers.co.za/mags/cosmo.html). Thus, the intended, or 'implied', reader is probably twenty-something, upwardly mobile and, as yet, free from the responsibilities of motherhood. Crossover and pass-on readership does, however, occur (McCracken, 1996:97).

Publishers and editors are aware of the 'aspirational' role of their magazines, and in the case of teenagers, the aspiration is to be older (Ballaster et al, 1996). This view is corroborated by Helen Gurley Brown, founding editor of Cosmopolitan magazine: 'Cosmopolitan is every girl's sophisticated older sister' (Ferguson, 1983:37).

The title reflects the global success of the brand, which 'attests to the successful marketing of a globe-girdling ideology of womanhood - the cult of femininity for export' (Ferguson, 1983:36). The magazine is an example of the way in which western commercial understandings of femininity have been adopted elsewhere in culturally diverse countries. The title appeals to the reader on the level of the 'global sisterhood' myth and to the need for the 'modern, liberated' woman to be upto-date on international trends. This enables an imaginative connection with likeminded women across the world.

The women featured on the covers are predominantly white (11 of the 13 issues examined featured white models). Most cover models are international celebrities. The Cosmopolitan copy writing style, which makes extensive use of alliteration and punning, forms part of the flirtatious yet straight-talking 'Cosmo-girl' image.

\section{True Love}

True Love is largely read by black women. The relaunch in 1995 was effected by Khanyisile Dhlomo-Mkhize. Since then, circulation and readership figures have steadily increased. The majority of readers are young (with 43.6 percent belonging to the 16-24 age group and 34.3 percent belonging to the $25-34$ age group), black (96.3 percent), and, of course, female (60.4 percent).

True Love claims to provide a 'lifestyle role model [that readers] can aspire to'.This aspirational element is one of two primary dispositions common to consumer magazines for black South Africans. True Love, like other magazines, and specifically those intended for black South Africans, presents images of a typically middle-class lifestyle as desirable, promoting a culture in which leisure and consumption go hand in hand (Laden, 2000). Hence, says Laden (2000:8): 
magazines render meaningful, without necessarily always putting into action, a shared repertoire of everyday experiences, lifestyle options, and social practices best described, from a Western or European standpoint, as typically 'middle-class' or 'bourgeois'.

The aspirational role is important within the post-apartheid context because, by depicting images of black success, they provide 'new social options' (Laden, 2000:11) and allow 'South Africa's black middle-class to create, disseminate, and legitimize new definitions of themselves, and hence to revise the cultural categories hitherto ascribed to them' (Laden, 1998:22). True Love's publishers have been less committed 'to a feminist programme than to a broader agenda of socio-semiotic change in South Africa' (Laden, 2000:17). As Dhlomo-Mhkize (MagFocus, 1998) states, True Love:

provides meaningful direction to people who have been afforded hitherto undreamed-of opportunities and possibilities. It gives its readers the advice and answers to deal with the ensuing doubts, confusion and challenges this paradigm shift represents.

The overtly aspirational and didactic stance of black-targeted magazines serves a significant post-apartheid function, in that it offers practical advice to emerging professionals, more integrated into the economic and business environments than ever before. By portraying images of black success, such magazines provide readers with new means for (material) self-expression, in ways that encourage others to succeed in order to achieve a similar lifestyle and level of economic involvement previously denied them. Others, however, suggest that by emphasising the values of individualism and consumption, through portraying images of success, magazines perpetuate the myth of the self-made man and undermine the black class struggle that requires structural rather than liberal individualist change. These images serve a purely economic function, with glossies 'stoking black pride while cultivating a product-hungry audience for corporate advertisers' (Leslie \& Foss, 2000:3). Such images may also widen the gap between the 'haves' and the 'have-nots' within the black community by 'promoting the imitation of the aesthetic values and consumption habits of the white privileged class and the bourgeois aspirations of middle class blacks' (Leslie \& Foss, 2000:9).

If indeed magazine covers do create an idealised reader-image of the group advertisers seek to reach (McCracken, 1996:97), then True Love presents local celebrities who - through being black, successful and South African - are held up as role models for, or perfected versions of, the readers themselves. The covers of all 13 issues studied featured local women emblematic of black success. These allow black women to recognise themselves as they provide them with an image of 'ideological positionality' with which they can identify and relate to (McCracken, 1996:99).

However, three regular items which one would definitely not find in Cosmopolitan are worth mentioning, for what they suggest about the different readers targeted: the bridal competition; the True Love/ Ellerines kitchen feature; and the True Love/ Ellerines traditional recipe competition. This element of True Love suggests that the readership is more traditional in its interest in home-related industries and perhaps live in either a more patriarchal or working class society, where women are more likely to assume traditional gender roles. However, the True Love /Ellerines kitchen 
feature also points to the possibility that home economics presents black women who have not had tertiary qualifications with viable career options.

This feature is also an example of the way in which black consumer magazines, by reinterpreting notions of westernisation and modernity, are responsible for the urbanisation and embourgeoisification of black South Africans (Laden, 1998:5). For instance, the June 2000 issue covered the True Love kitchen international gourmet advanced cookery course, intended to 'help readers improve their cooking and entertaining skills'. Similarly, the August issue featured a Mother's Day lunch, where participants discussed 'issues affecting women and how to entertain with wine and cheese'.

True Love attracts 10 percent less advertising than Cosmopolitan. It contains slightly more features and double the amount of regulars, with a slightly smaller emphasis on fashion and beauty (11 percent compared to the Cosmopolitan's 18 percent), and a slightly greater emphasis on food and décor.

The majority of True Love features highlight social issues. So much so, that this category (26 percent of feature space) was placed first, in comparison to the Cosmopolitan sample, where social issues comprised six percent, with the category ranking sixth in terms of importance. Half of the articles dealing with social issues were concerned with gender-related issues. The rest dealt with issues relevant to South African society and the African community in general. Fewer articles dealt with popular psychology topics but the same amount of focus was given to the topic of sex. Significantly fewer articles were on love relationships. Three categories were given a much greater emphasis in True Love, with figures double or more than those for the Cosmopolitan - those were celebrities, work and social issues.

Some of the gender related articles were explicitly concerned with feminist and empowerment issues more so than in Cosmopolitan, which tends to employ an assertive postfeminist attitude rather than 'spell out the facts', and True Love is often more concerned with the progress of the individual than the progress of women worldwide.

\section{Brand extensions}

True Love's brand extensions include 'True Love Live', a regular radio show that deals with topics covered in the magazine; and True Love self-improvement and empowerment workshops. Cosmopolitan brand extensions include the short-lived television show; hair accessories; a diary and 'hunk' calendar. Whereas Cosmopolitan's extensions are commercially driven, concerned with increasing brand awareness and sales, True Love's outside involvements appear to serve more of a social function, concerned with the education and empowerment of women. True Love's brand extensions are in keeping with the magazine's image as practical helper, informal educator and role model.

In sum, the results showed that Cosmopolitan and True Love are committed to different feminist agendas. Cosmopolitan is chiefly concerned with the maintenance and improvement of the self, and the navigation of heterosexual love relationships. It conveys an assertive, postfeminist attitude and provides an example of how the ideology of feminism has been incorporated into consumer discourses on a global scale (Macdonald, 1995:91).

The True Love analysis supported Laden's (1997:128; 2000:11) claim that consumer magazines for black South Africans are more overtly aspirational and didactic than those intended for a predominantly white readership. The magazine 
foregrounds the achievements of local role models, presents middle-class lifestyle practices as desirable, and includes a great deal of practical advice and information. The prevalence of features concerned with social issues, together with the nature of the magazine's brand extensions, reveals True Love's commitment 'less to a feminist programme than to a broader agenda of socio-semiotic change in South Africa' (Laden, 2000:17).

\section{Comparison of content}

\begin{tabular}{|c|c|c|}
\hline Category & Cosmopolitan & True Love \\
\hline Advertisements & $42 \%$ & $34 \%$ \\
\hline Features & $22 \%$ & $24 \%$ \\
\hline Regulars & $10 \%$ & $20 \%$ \\
\hline Beauty and Fashion & $18 \%$ & $11 \%$ \\
\hline Body \& Soul & $3 \%$ & - \\
\hline 'Cosmo Helps' (Advice) & $3 \%$ & - \\
\hline Health & - & $4 \%$ \\
\hline Food \& Décor & $2 \%$ & $5 \%$ \\
\hline Competitions & - & $2 \%$ \\
\hline
\end{tabular}

\section{$\square$ Cosmopolitan $\quad$ True Love}

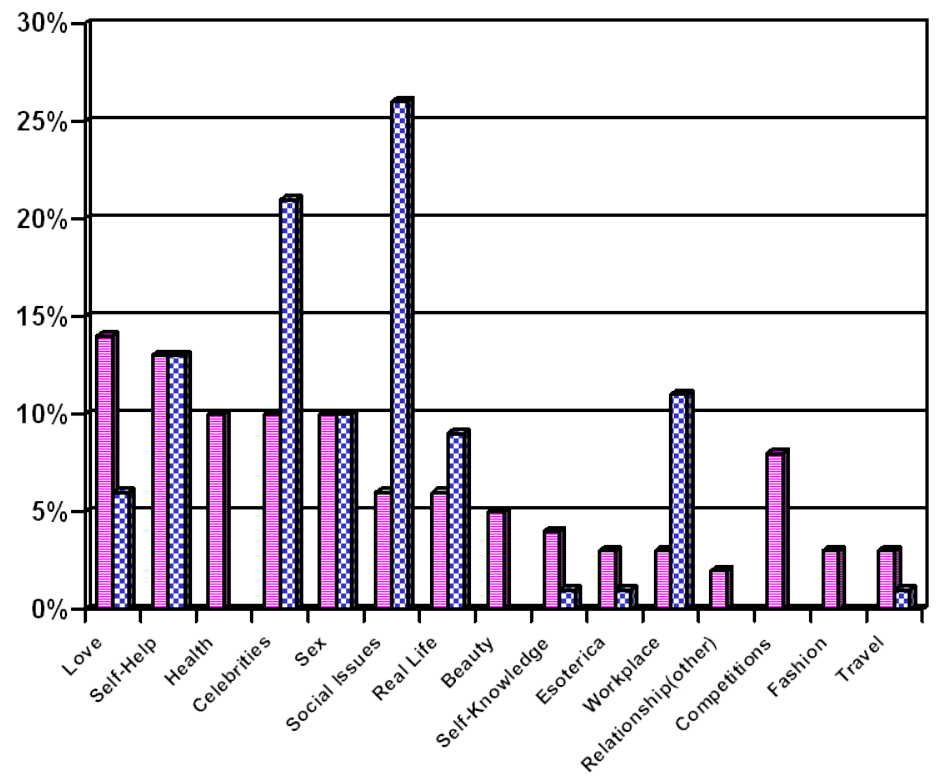

Table 2: Feature Categories

Five categories derived from the Cosmopolitan sample were not present in the True Love feature articles: Relationship (Other), Fashion, Beauty and Health, all of which were in separate sections of the magazine and were not represented in the features themselves. Although the Cosmopolitan sample also has its own sections for Beauty, Fashion and Health, these topics are also frequently covered in the features section. 


\section{ANALYSIS}

The focus group participants were all familiar with the magazine genre and cited the fashion, beauty, sex, gossip and love relationship categories as definitive of the genre. Also mentioned was a general focus on 'women's interest' subjects, based on an awareness that magazines are gender specific. Similarly, men's magazines were believed to provide insight into masculinity. The most popular magazine among the respondents was Cosmopolitan, followed by Elle and Marie Claire. True Love was, understandably, only read by the black participants. All of the schoolgirls interviewed perceived magazines as cultural developmental markers that play a role in the process of moving from girlhood though adolescence and into womanhood. Some said that Cosmopolitan was read in the absence of any South African teenage magazine. The participants who were familiar with teen magazines felt that their 'pop star pin-up' quality made them more suited to adolescents and girls younger than themselves. The consensus was that teenagers are developing at a faster rate and are therefore choosing adult titles at a younger age than that targeted. Participants did acknowledge, however, that cross-over readership does occur, within the family especially.

In the focus groups dominated by people who did not read women's magazines regularly, the readers showed a self-consciousness that suggested an awareness of the genre's 'low' status and relative expense, making magazine reading an almost 'illicit' pleasure. Answers to the question of why they read magazines confirmed that the enjoyment of the medium is closely tied to its seriality, its (visual) material form, and the inherent idealism of the form.

\section{Interpretive Repertoires}

The two most descriptive repertoires identified by Hermes (1995:31) are the 'easilyput-down repertoire' and the 'repertoire of relaxation'. Readers consume magazines for their adaptability, specifically their ability to adapt to a noisy background. The 'repertoire of relaxation' demonstrates how interpretive repertoires are used to explain, justify and legitimise behaviour. This repertoire also points to the fact that media use is often secondary and is not always considered meaningful. The following statement is an example:

Ingrid: You know, I am not reading it for the reason that the magazine is being sold. It's sort of like for the same reason I watch TV - I want to switch off.

The 'repertoire of practical knowledge' stresses the practical uses of magazines, and thus appeals to the reader's 'pragmatic and solution-oriented' fantasy self, who is, for instance, up to date on new products and 'able to come up with solutions for virtually anything’ (Hermes, 1995:39). This repertoire was invoked by my own informants, who spoke of the usefulness of dress patterns, nutritional advice, beauty tips and career information. The 'repertoire of emotional learning and connected knowing', on the other hand, values experience and intuition over reason, and is concerned with human emotions.

Readers who make use of this repertoire believe knowledge comes from experience and that learning about the experience of other people can empower one to handle any potential future crises. This repertoire addresses the fantasy of being in control and emotionally prepared - 'the fantasy is also of being a "wise woman", (Hermes, 1995:45). The use of real-life stories and self-help literature is cited under 
this repertoire. In the case of Cosmopolitan, this repertoire is self-directed and internalised, rather than concerned with others, like family members (as might be the case with magazines aimed at older women) (Hermes, 1995:112). Although this repertoire was cited less often than the repertoire of 'practical knowledge', some participants did read magazines as a form of emotional learning. My findings confirmed that readers largely draw upon the repertoires of 'practical' and 'emotional' learning to explain why they read women's magazines.

\section{Positive and negative features of the women's magazine}

When asked to list a positive feature of women's magazines, the respondents answered in terms of the repertoires listed above and also highlighted their informative, educational and aspirational roles. Related to 'emotional learning' is the aspirational element. True Love readers were particularly motivated and inspired by their reading. Another positive feature mentioned was in keeping with the idea that the women's magazine provides a 'feminized space' (Beetham, 1996:3).

Among the negative aspects of women's magazines mentioned was the genre's over-reliance on gender stereotypes. Others also responded negatively to the idealistic portrayals in women's magazines and their perceived over-emphasis on beauty ideals. These idealised images were attributed with negatively affecting the reader's mood, or sense of self. When asked to describe their typical feelings or thoughts when looking through a women's magazine, Charlize (17) said she found the experience 'depressing, slightly'. Jalit (20) said magazines 'make you feel so ugly, you know. Like... you look in here [flipping through the Cosmopolitan] - there's not one plump person in here, there's not one ugly face in here. So, like, it says to you basically... you're like "wow, I wish I could be like that".' Natalie (15) suggested that it is the status of women's magazines as 'authorities' on issues of beauty and physical appearance that may lead to a reader's feeling of inadequacy in comparison to the perfected images displayed on every page.

However, participants generally showed an understanding of the way in which body issues are explained psychologically. There was recognition that a 'low selfesteem' contributed to body-dissatisfaction and obsessions with weight.

There are, of course, cultural differences in body ideals specifically within the context of multicultural South Africa. On the subject of fashion, Nthati (25) said she appreciated the fact that True Love features pictures of large women. When I asked another group whether black girls were becoming more weight conscious, the answer was yes. The implication was that increasing modernity and the globalisation of the media is resulting in a more westernised definition of beauty. Buhle (21) said she believed that 'the pressure is on, on the younger generation to stay slim and thin, the western way or ideal'. She also made reference to an interaction she had had with her grandmother, which revealed a disappointment with the erosion of traditional beauty ideals:

Buhle: I think it's society, even now. There was a time when, I, um, got angry with my grandmother because she commented on my weight and I couldn't understand how she could be saying these things. She's supposed to be an African woman, why do you say I'm getting fat?

In discussing the positive and negative features of women's magazines, some girls described magazines as contradictory forms. In particular, the juxtaposition of the 
themes of self-acceptance and self-improvement were said to be a source of tension. For instance:

Ingrid: They spend half the magazine telling you not to worry about your body and the other half shows you how to improve yourself. It's not how to improve your self-image but how to improve your looks.

\section{The topic of sex}

The participants all showed a heightened awareness of the media's over-reliance on sexual imagery and, like the participants in Kehily's (1999) study on whether teenage magazines serve as resources for sexual learning, my groups were discerning readers who generally objected to overtly sexual content. Some objected to the prevalence of 'half-naked women', especially on the covers. Some commented that such depictions are making women's magazines more like men's magazines.

Like Kehily's participants, the participants in my study revealed a general aversion to material of an explicit nature, but they recognised that magazines can and do serve as useful sources for sexual information. Women's magazines in general, and Cosmopolitan specifically, were accused of giving inaccurate portrayals of female sexuality by suggesting that 'everybody sleeps around' (Paige, 16). The sexual confidence and assertiveness depicted in magazines was said to betray certain gender differences:

Danielle: I think they're aiming towards a very independent woman. But then they try and gain that independence through their sexuality and stuff, which I don't think many independent women really do.

However, some participants did express an appreciation for the sex-related articles, even when their peers disagreed. Buhle (21) said that she thought it strange that none of the group had mentioned reading magazines for sex tips, saying that she read Cosmopolitan for that specific reason, 'every now and then'.

\section{Reading 'against the grain'}

Participants who showed a sense of belonging to a subculture that separated them from mainstream youth, and those who explicitly defined themselves as nonmagazine readers, were dismissive of the magazine as 'authority'. The tendency to mock the magazine genre was also more pronounced among those who came from well-educated backgrounds. Some of the comments made by these participants confirmed that "irony...in general seems to be the weapon of the "cultural capitalist"' (Hermes, 1995:136).

Few participants claimed identification with the 'imagined community' of magazine readers. Firstly, the non-readers' criticisms tended to silence the magazine readers, who were generally aware of the 'low' status of the genre. Secondly, the magazine readers revealed their own ambivalent responses to the form, and showed an awareness of the limitations of the genre in their own mocking and criticism of women's magazines. There was instead a greater tendency towards distancing oneself from an 'imagined community'.

However, identification with an 'imagined community' was clearly experienced by True Love readers, who expressed pride in belonging to the 
community. I asked whether a person's magazine choice says something about the reader and, if so, what would the public display of True Love say about the reader? Buhle (21) responded that such a display would identify the reader as a 'liberated woman' with 'ambition and success'. The True Love readers all remembered when they first started reading the magazine and remained regular readers.

\section{The global and the local}

One participant felt that the over-reliance on foreign content undermines the credibility of local magazines. In Cosmopolitan, this trend of using content material syndicated from international editions is related to the marketing of the magazine as a 'global brand' (Murray, 1998:148). However, Marion (16) said that part of the excitement of reading a magazine came from feeling connected to 'the outside world... what's happening overseas. Marian clearly enjoys feeling connected to 'the "globe-girdling” cult of femininity advocated by women's magazines' (Ferguson, 1983:36). Marion's statement can also be read as an illustration of the sense of cultural isolation that some white South Africans feel, many of whom prefer to identify with a global, or European, group sensibility.

True Love was seen as more 'real' than Cosmopolitan, in that it depicted 'normal' people and gave more practical fashion information. The magazine was noted for making more sincere efforts to cultivate self-confidence.

All agreed that the two magazines were targeted at different readerships in terms of culture and race. The covers were taken as proof of this, as were the images on the inside pages. Black girls felt alienated from women's magazines other than True Love, which depict mostly white westernised women. Ingrid suggested that magazines such as True Love could serve as vehicles for greater cross-cultural understanding within the South African context. She referred to an article she had read in True Love that had revealed to her the cultural differences in attitudes towards sex. The True Love readers were less self-conscious about their reading practices, and freely admitted to reading magazines for advice on relationships and beauty information. Other differences concerned the different approaches to fashion; the different subject matters dealt with in the articles and the different kinds of products advertised.

The participants displaying a greater amount of 'cultural capital' were generally those who did not define themselves as magazine readers, or who defined themselves in terms of a subcultural identity. Their attitudes also made apparent how 'media readers who have already questioned conventional categories of gender, ethnicity or sexuality in their own practice have at least a chance of being more resistive readers than their conservative peers' (MacDonald, 1995:220).

In some groups, consensual tendencies silenced the opinions of the selfconfessed magazine readers, aware of the 'low' status of the genre. However, given the chance, magazine readers themselves expressed mixed feelings about the contradictory tendency of women's magazines to focus on both self-acceptance and self-transformation. Although there was recognition that 'low self-esteem' was the greatest contributing factor in determining body dissatisfaction, the constant repetition of messages related to physical appearance was considered potentially dangerous. Above all, it was the readers of Cosmopolitan who expressed irritation at the idealistic magazine form. The True Love readers felt proud to be part of the 'imagined community' of readers and were inspired by the magazine's aspirational messages. 


\section{CONCLUSION}

Women's magazines give the intangible concept of femininity a material form. By operating as 'feminised' spaces, they have been central to the definition and maintenance of western female identity (Murray, 1998:95).

In a positive light, women's magazines have popularised feminist ideologies (Wolf, 1990: 71). They are aspirational devices that provide 'moments of empowerment'. Women's magazines connect the reader to a global imaginary and a particular pleasure involves the sense of belonging to a global or more specifically local 'imagined community' of women (Anderson, 1983:15-16).

Consumer culture cannot be viewed in purely oppressive or celebratory terms, neither can the media texts which form part of it (Murray, 1988). Consumer culture needs to be understood from a perspective that finds a balance between creativity and constraint (Mackay, 1997:10). Women's magazines are marked by their ambiguities: the central paradox revealed in the genre is the idea that femininity is a given and is yet still to be achieved (Beetham, 1996:1; Ferguson, 1983:59). These inconsistencies are to be expected, 'since media absorb the discourses of different social institutions, they present a variety of positions and perspectives that are at times in direct opposition to one another' (Spigel, 1992:8). Women's magazines can be regarded as discursive sites-of-struggle where meanings (about femininity, specifically) are contested and made.

In terms of the differences between True Love and Cosmopolitan, the former's readers were proud to be identified as such, and found the magazine to be informative and inspiring. Cosmopolitan readers were able to distance themselves from the women's magazine genre, largely as a result of their own ambivalent reactions to the contradictions within the form, which are more pronounced in the idealistic postfeminist Cosmopolitan. True Love was felt to provide a more positive role, one that includes promoting cross-cultural understanding within post-apartheid South Africa.

The focus groups demonstrated, above all, that participants who have a greater amount of 'cultural capital' are better able to deconstruct media messages and adopt more oppositional reading positions. Future research could build upon the findings of this study by using a larger and more representative sample, including a greater percentage of True Love readers, and by including more participants who do identify themselves as members of the 'imagined community' who read women's magazines.

\section{REFERENCES}

ABC Circulation figures. 2000. (January to June)

AMPS Survey. 1999. Bryanston, South African Advertising Research Foundation.

AMPS Survey. 2000. Bryanston, SAARF.

Anderson, B. 1983. Imagined communities: Reflections on the origins and spread of nationalism. London: Verso Editions.

Baehr, H. \& Gray, A. (eds.) 1996. Turning it on: A reader in women and media. London: Arnold.

Ballaster, R., Beetham, M., Frazer, E. \& Hebron, S. 1996. A critical analysis of women's magazines. In H. Baehr and A. Gray (eds). Turning it on: A reader in women and media. London: Arnold.

Barker, C. 1999. Television, globalization and cultural identities. Philadelphia: Open University Press. 
Bausinger, H. 1984. Media, technology and daily life. Media, Culture and Society, Vol. 6:343-351.

Beetham, M. 1996. A magazine of her own? Domesticity and desire in the women's magazine, 1800-1914. London: Routledge.

Bocock, R. 1993. Consumption. London: Routledge.

Bordo, S. 1996. 'Material girl': the effacements of postmodern culture. In H. Baehr \& A. Gray (eds). Turning it on: A reader in women and media. London: Arnold.

Bourdieu, P. 1984. Distinction: a social critique of the judgement of taste. Cambridge, Massachussets: Harvard University Press.

Claasen, G. 1998. Magazines: Life’s own story. In A. S. De Beer (ed.) Mass media towards the millenium: The South African handbook of mass communication. Pretoria: J.L. Van Schaik.

Cosmopolitan. October 1999-October 2000. National Magazines, Cape Town.

Coullie, J. 1991. 'Not quite fiction': The challenge of poststructuralism to the reading of contemporary South African autobiography. Current Writing, Vol. 3:1-23.

Craik, J. 1994. The face of fashion: Cultural studies in fashion. London: Routledge.

De Beauvoir, S. 1972. The Second Sex. Harmondsworth, Middlesex: Penguin. First published as Le Deuxieme Sexe, 1949. Paris: Gallimard.

Entwistle, J. 2000. The fashioned body: Fashion, dress and modern social theory. Cambridge: Polity Press.

Fairclough, N. 1992. Discourse and social change. Cambridge, Polity Press.

Ferguson, M. 1983. Forever feminine: Women's magazines and the cult of femininity. London: Heinemann Educational Books.

Focus Group transcripts. 2001.

Foges, C. 1999. Magazine design. Switzerland: Rotovision SA.

Foucault, M. 1982. Afterword: The Subject and Power. In Dreyfus, Hubert L. \& Rabinow, Paul. (1982). Michel Foucault: beyond Structualism and Hermeneutics. Chicago: The University of Chicago Press, 208-226.

Foucault, M. 1985. The history of sexuality, Vol. 2: The use of pleasure. New York: Random House.

Foucault, M. 1986. The history of sexuality, Vol. 3: The care of the self. Harmondsworth: Penguin.

Foucault, M. 1988. Technologies of the self. In L. Martin, H. Gutman \& P.Hutton (eds). Technologies of the self: A seminar with Michael Foucault. Amherst: University of Massachusetts Press.

Frazer,Elizabeth 1987.Teenage Girls Reading Jackie. Media Culture and Society vol 9 (excerpt reprinted in: Bob Ashley (ed) 1989. The Study of Popular Fiction: a source book London: Pinter Publishers.

Gough-Yates, A. 2000. 'Sweet sell of sexcess': The production of young women's magazines and readerships in the 1990's. In D. Berry ed). Ethics and media culture: Practices and representations. Oxford: Focal Press.

Hermes, J. 1995. Reading women's magazines. Cambridge, Polity Press.

Hermes, J. 2000. Of irritation, texts and men: Feminist audience studies and cultural citizenship'. International journal of Cultural Studies, Vol 3(3):351-365.

Kehily, M. J. 1999. More sugar? Teenage magazines, gender displays and sexual learning. European Journal of Cultural Studies, Vol. 2(1):65-89.

Laden, S. 1997. Middle-class matters, or, how to keep whites whiter, colours brighter, and blacks beautiful. Critical Arts, Vol. 11(1\&2):120-141.

Laden, S. 1998. Who's afraid of the black bourgeoisie? Consumer culture and the making of a new South Africanness. Paper presented at the Second International 
Crossroads for Cultural Studies Conference. June 28-July 2, 1998, Tampere, Finland.

Laden, S. 2000. Consumer magazines for black South Africans: Toward a 'cultural' economy of the South African (print) media. Paper presented at The Political Economy of the Media in Southern Africa seminar, Graduate Programme in Cultural and Media Studies. April 25-29, 2000, University of Natal, Durban.

Laden S. 2001. Magazine matters: Toward a cultural economy of the South African (print) media. In Tomaselli, K.G. \& Dunn, H. (eds) Media, democracy and renewal in southern Africa. Colorado Springs: International Academic Publishers.

Leslie, M. \& Foss, M. 2000. U.S and South African images of black success: A pilot study in transnationalization and hegemony. Safundi: The journal of South African and American comparative studies, Vol. 2 (2):1-13.

Lewis, L. 1987. Female address in music video. Journal of communication inquiry, Vol 11(1):73-84.

Macdonald, M. 1995. Representing women: Myths of femininity in the popular media. London: Arnold.

Mackay, H. (1997) Consumption and everyday life. London, Sage/ The Open University Press.

McCracken, E. 1996. The cover: Window to the future self. In H. Baehr \& A. Gray (eds). Turning it on: A reader in women and media. London: Arnold.

McQuail, D. 1994. Mass communication theory: An introduction. Third edition. London: Sage.

McRobbie, A. 1981. Just like a Jackie story. In A. McRobbie and T. McCabe (eds). Feminism for girls: An adventure story. London: Routledge \& Kegan Paul.

McRobbie, A. 1996. More! New sexualities in girl's and women's magazines. In J. Curran, D. Morley and V. Walkerdine (eds). Cultural studies and communications. London: Edward Arnold.

Moores, S. 1997. Broadcasting and its audiences. In H. Mackay (ed). Consumption and everyday life. London: Sage.

Morley, D. 1980. The 'nationwide' audience: Structure and decoding. London: British Film Institute.

Murray, S.A. 1994. Tribute and attributed meaning: Reading 'the magazine'. Current Writing, Vol. 6(2):63-76.

Murray, S.A. 1998. Mediating contemporary cultures: Essays on some South African magazines, malls and sites of themed leisure. Ph.D. Thesis, University of Natal, Durban.

Negrin, L. 2000. Cosmetics and the female body: A critical appraisal of poststructuralist theories of masquerade. European journal of cultural studies, Vol. 3(1):83-101.

Neuman, W. 1997. Social research methods: Qualitative and quantitative approaches. Fourth edition. London, Allyn \& Bacon.

O’Sullivan, T., Sanders, D., Montgomery, M., Hartley, J. \& Fiske, J. 1994. Key concepts in communication and cultural studies. London: Routledge.

Pease, B. 2000. Recreating men: Postmodern masculinity politics. London: Sage.

Polce-Lynch, M. 1998. Gender and age patterns in emotional expression, body image, and self-esteem: a qualitative analysis. Sex roles: A journal of research, June: 119.

Potter, J. \& Wetherall, M. 1987. Discourse and social psychology: Beyond attitudes and behaviour. London: Sage.

Storey, J. 1999. Cultural consumption and everyday life. London: Arnold. 
Thesander, M. 1997. The feminine ideal. London: Reaktion Books.

True Love. October 1999- October 2000. National Magazines, Cape Town.

Van Zoonen, L. 1994. Feminist media studies. London: Sage.

Weedon, C. 1987. Feminist practice and poststructuralist theory. Oxford: Blackwell.

Wolf, N. 1990. The beauty myth. London: Vintage.

Wood, L. \& Kroger, R. 2000. Doing discourse analysis. London: Sage. 